Asia seem determined to be flexible, are determined to recruit the best people they can find as teachers and are conscious that much of their income in the long run will depend on the value that industry puts upon them. Of necessity, the university presidents who put their case last week are not the ones best qualified to speak of the freedom ordinary academics enjoy.

On assessment, participants last week offered a variety of opinions. For zu Putlitz, a prior consideration in assessing the quality of a group of academics is secular success: what is the age distribution, how often have people been offered jobs elsewhere (a plus), and how often does the group offer its own graduates permanent positions (a minus)? Only then does he think it worthwhile looking carefully at people's publications and the status of invited lectures at international meetings.

Minoru Oda, the founding director of Japan's institute of advanced study at Nala, near Kyoto, argued that the assessment of teaching is more difficult when the crucial function is "to convey a sense of excitement to young people", but Swinnerton-Dyer (advocating assessment by more senior and more junior people as well as by students "who take the responsibility very seriously"), preferred to trust to instinct: "I know one [a good teacher] when I see one",

Langenberg, on the other hand, quoted with approval the decision of one of the three campuses in his system to hire a clinical psychologist to assist with the assessment of the teaching function. "Rarely do we use professionals", he declared. Chung, by contrast, held that a good teacher is one who "refrains from preventing the natural development of students" while Lee held that the best teachers were not necessarily those who explained things most clearly.

Some institutions in Japan are (according to Oda) preparing for the individual assessment of academics, but there is little agreement on how it should be done. And nobody answered the speaker from Tsukuba who asked how teaching could flourish when the "rewards system" favoured research.

Where does that leave the universities of Japan, the first of the Pacific countries to make its economic mark? There are more than 100 public universities (most controlled by Monbusho, some by prefectures) and several hundred private universities (most of which earn a government subsidy, but whose students pay high tuition fees, and whose academics are often part-timers). There have been whispers of anxiety for several years, ever since Japan (still the richest country in the Pacific, perhaps the world) began looking over its shoulder at the industrial achievements of its neighbours.

Last week, discontent spilled over in public. Arima was the first to make the point, but in the politest language. True, Monbusho's budget has been increasing, but the funds need to be spent selectively; there is "no need to give the same things to all universities at the same time". The universities have been slow to develop $\mathrm{PhD}$ programmes, and potential employers have been slow to appreciate the value of such developments.

Who are Japan's academics? Professor Robert Geller, a tenured professor of geophysics at the University of Tokyo, complains that there are not enough non-Japanese. $\mathrm{He}$ is one of only 25 tenured academics at Japanese national universities, out of a total teaching staff of 35,000 , who are not Japanese nationals. (There are ten times as many untenured academic staff from overseas.)

Geller wants more, not to provide jobs for people unemployed elsewhere, but for the sake of the Japanese universities themselves. Inbreeding is a problem. At the University of Tokyo, 86.8 per cent of academics are graduates of the same university. The percentage of teachers at the

\title{
Conditions for excellence
}

The conference agreed to a statement previously discussed in detail by the speakers, and whose chief points are as follows:

Cultural, linguistic and social differences require that university systems differ among themselves, but there are common principles that should assist in the cultivation of excellence.

First, excellence should be the primary criterion in decisions on appointments and funding.

Second, excellence in research is not an excuse for mediocrity in teaching.

Third, regular and objective assessment of research and teaching is essential.

Fourth, flexibility (of institutions and

departments) is essential in responding to changing circumstances and in seizing research opportunities (especially across disciplines).

Fifth, an institution or department largely relying on internal appointments is unlikely "to become or remain" a centre of excellence. "As far as possible", foreign staff should be treated on the same terms as nationals.

Sixth, networking internationally is crucial. Seventh, institutions need to be free to decide how the bulk of their income is to be spent on research and teaching, with external funding bodies interfering only to the extent required to ensure that public money is properly spent.

Copies of the full report are available on request.
University of Kyoto who graduated there is smaller, at 80 per cent. Elsewhere in Japan, the inbreeding index is more like 50 per cent.

The explanation of that phenomenon was agreed by Geller and Sukeyasu Yamomoto, professor of physics at Sophia University (whose $\mathrm{PhD}$ is from Yale): appointments to academic vacancies are made by groups of academics working in a particular field, then automatically approved by the department and the faculty to which the group belongs - and almost never questioned by Monbusho.

The result is what Yamomoto called "selfishness and irresponsibility". Faced with the need to fill a vacancy, academics think first of their own students, often then of their chums. "These are strong words, I know," Yamomoto said last week, "but I believe them to be true." One ironical result of the recent pressure on university funds, which requires a 3 per cent reduction of faculty numbers over five years, is that professors continue to be appointed "at the expense of [the numbers] of junior faculty".

Yamomoto also said last week that academic freedom in Japan is essentially a sham. Professors are indeed free to choose the fields in which they work, with the consequence that an engineering department with "100 professors may have 100 laboratories", but the "total dependence" of all academics on Monbusho (for approval as well as funds) means that "it is virtually impossible to behave in defiance of Monbusho", yet there is "no such thing as accountability, only irresponsibility". Yet the only freedom that professors can be sure of is "the freedom not to be sacked".

The root of Monbusho's power was identified by Shinichi Yamomoto of Tsukuba University, whose task is the study of the modern university. This Yamomoto may well be a means by which Dr Leo Esaki, the man who gave IBM the Esaki diode before returning to be the president of Tsukuba, seeks to deflect some of Monbusho's influence.

His explanation of the ministry's power is the practice by which the ministry supplies the administrative heads of universities. The crucial post is that of secretary-general, but registrars and financial administrators are also appointed in this way. "We have no profession of independent university administrators", said Yamomoto.

Esaki, chairman of the panel discussion in which this plain-speaking bubbled up, plainly relished his position. After one outspoken criticism of the ministry, he declared that "If there are members of Monbusho in the audience" [there were], "I'll give them time to answer." He paused just long enough to let people sense the challenge had gone by default.

John Maddox 